\title{
Actualizarea și structura costurilor la lucrările de bază pen- tru corectarea torenților. Studiu de caz in bazinul torențial Doroteia, județul Suceava
}

\section{Clornei}

\section{Introducere}

Punerea in valoare a terenurilor degradate din bazinele hidrografice torenţiale presupune realizarea unui complex de lucrări menite să oprească eroziunea și să readucă în cel mai scurt timp terenurile în circuitul economic, cu minimum de cheltuieli. În general aceste lucrări de ameliorare sunt însoțite de lucrări hidrotehnice care sunt executate în vederea
Ciornei I. 2019. Updating the structure of costs of basic works of torrents control. Case study in Doroteia torrential watershed, Suceava county. Bucov. For. 19(2): 107-122.

Abstract. When assessing the costs of torrents control works we customary use the unit price of each type of work, differentiated against construction materials and technologies. In the feasibility study, for transverse hydrotechnical works, omnipresent across all torrent control works, there is no cost differentiation depending on the height of the works (from sills to check dams). All the while the economic effect of works built in the past is difficult to assess, lacking the initial designs and having no clues about the cost structure in the past, as well as about deployed technologies. Whatever analysis on this topic shall rely on updated costs of works. The paper demonstrates that updating bygone costs of investments built more three decades ago cannot be based on past expense estimations, and whatever method based on price indices produces abnormal results. The paper also highlights some significant dfferences between unit prices of different types of works even though the homogeneity criterion is met by the materials and deployed technologies. Keywords: torrent control works; cost estimate.

Author. Ciornei Ioan (ioanciornei@usv.ro) - Ștefan cel Mare University of Suceava, Forestry Faculty, 13 Universității, 720229 Suceava, Romania.

Manuscript received December 16, 2019; revised December 29, 2019; accepted December 29, 2019; online first December 31, 2019. 
tă un minimum de lucrări hidrotehnice care să apere obiectivul respectiv, iar concomitent se intervine, după caz, cu lucrări de împăduriri în vederea diminuării efectului torențial.

Prin realizarea investitiilor pentru amenajarea torenților (Munteanu, et al. 1993, Clinciu 2001, Gașpar 2005, Ciornei și Grudnicki 2010, Clinciu 2011) se elimină/diminuează cheltuielile neproductive cauzate de viiturile torențiale, se limitează pagubele pricinuite culturilor agricole sau forestiere și cheltuielile cu întreruperea circulației, distrugerile de bunuri materiale etc.

Investiția pentru lucrările de amenajarea a bazinelor hidrografice torențiale, se justifică economic (Anonymous 2017) prin analiza cost-beneficiu (ACB). Bazată pe teoria economică a bunăstării (Griffin 1998), ACB implică compararea costului unui proiect cu beneficiile pe care poate să le aducă (Drăgoi 2000, Milescu 2002, Drăgoi 2008, Ciornei și Drăgoi 2014). Aceasta permite să se determine variantele care maximizează avantajele și presupune exprimarea în valoare monetară a tuturor efectelor: directe, indirecte și intangibile.

Principiile ACB defalcate, în mod special la problemele de prevenire a riscurilor sunt următoarele (Duclos, et al. 1999):

(i) un proiect este acceptabil punct de vedere economic dacă beneficiile (daunele evitate) sunt mai mari decât costurile potențiale ale lucrărilor de prevenire;

(ii) efecte asupra bunăstării sunt obținute prin compararea a cel puțin două scenarii: cu și fără lucrări;

(iii) evaluarea costurilor se bazează pe costurile de oportunitate socială;

(iv) beneficiile sunt pagubele medii evitate de către lucrări;

(v) transferurile nule de costuri şi beneficii sunt ignorate (nu dublă contabilizare);

(vi) gregarea temporală a efectelor cu ajutorul actualizării;

(vii) modificările bunăstării în plan non-monetar ar trebui să fie relevante.

$\mathrm{ACB}$ are o serie de avantaje și dezavantaje care sunt inerente în evaluarea economică în 108 general.

Costul sistemului de protecție (Treich 2005) este împărțit în costurile de investiții (costuri de construcție) și costurile de exploatare (inclusiv costurile de întreținere și reparații rezultate în urma evenimentelor violente). La aceste costuri directe, uneori se adaugă costurile indirecte, (întreruperea traficului pe un drum) sau costurile unor efecte greu de cuantificat (de ex. estetic); așadar în afară de costurile directe (Bouzit 1999) mai pot exista costurile necontabile (costurile intangibile).

La evaluarea costului lucrărilor de corectare a torenților se folosesc frecvent prețurile unitare pe categorii de lucrări (Anonymous 2017), diferențiate in funcție de natura materialelor de construcție și de tehnologia de execuție. In cazul lucrărilor transversale - omniprezente in toate sistemele de amenajare a torenților nu se face diferentiere intre preturile unitare de la baraje, praguri şi traverse.

In același timp, efectul economic al lucrărilor executate in trecut, este greu de realizat din cauza lipsei proiectelor și a schimbărilor majore de pe piața materialelor de construcție și a tehnologiilor de execuție. Orice astfel de analiză trebuie sa plece de la costurile actualizate ale lucrărilor.

Pentru estimarea costurilor pot fi utilizate diferite metode, în funcție de stadiul de execuție și vechimea lucrării (Brochot, et al. 2003):

(i) cel mai simplu caz este al lucrărilor noi, sau construite recent, pentru care există referințe recente ale prețurilor. $\mathrm{Cu}$ toate acestea, incertitudinea rămâne ridicată pentru aceste activități specifice în teren dificil, deoarece costul poate varia de la simplu la dublu între estimările dinainte și după executarea lucrărilor când apar intemperii ce modifică valoarea iniţială.

(ii) în cazul lucrărilor care urmează să fie construite în viitor, costurile derivă din cele anterioare, cu câteva măsuri de precauție suplimentare legate de actualizare (Milescu 2002, Drăgoi 2008) ca urmare a schimbării mediului tehnic și economic.

(iii) costul lucrărilor recente, poate fi, în general, determinat pe baza documentațiilor din 
arhive; trebuie doar să fie actualizat;

(iv) la lucrările mai vechi, pentru care în general lipsesc documentaţiile, actualizarea este irelevantă. $\mathrm{O}$ actualizare a lucrărilor mai vechi de 30 de ani este considerată abuzivă în economie (Verrier 1980). Singura soluție acceptabilă constă în estimarea costului acestor lucrări prin "înlocuirea" lor cu altele noi, realizate cu tehnica actuală, care sa aibă o eficacitate echivalentă cu a lucrărilor vechi.

Scopul principal al cercetărilor este de a analiza structura costurilor la lucrările de bază pentru corectarea torenților executate in trecut şi actualizarea costurilor acestora in conformitate cu standardele actuale.

Pentru atingerea acestui scop trebuie parcurse următoarele obiective:

(i) Identificarea unui bazin care să conţină un proiect complet cu lucrări executate într-o singură etapă, cu cat mai multe tipuri de lucrări, cu materiale si tehnologii de execuție omogene care pot asigura comparabilitatea;

(ii) Actualizarea costurilor lucrărilor de bază executate in bazin;

(iii) Comparații intre costurile actualizate $\mathrm{cu}$ ajutorul indicelui de actualizare si costurile rezultate din devize;

(iv) Determinarea prețului unitar pe categorii de lucrări;

(v) Statistici cu privire la rezultatele obținute.

In prezenta lucrare se demonstrează că actualizarea costurilor unei investiţii realizate cu mai bine de trei decenii in urmă nu se poate face decât pe baza devizelor de lucrări și că orice tentativă de actualizare bazată pe aplicarea indicilor de preturilor de consum (IPC) conduce la rezultate aberante. Lucrarea mai evidențiază existența unor diferențe semnificative între prețurile unitare ale diverselor tipuri de lucrări, chiar daca sunt îndeplinite criteriile de omogenitate in ceea ce privește natura materialului şi tehnologia de execuție

\section{Material și metodă}

\section{Localizarea cercetărilor}

Cercetările efectuate în cadrul prezentului studiu de caz s-au desfăşurat in bazinul hidro-
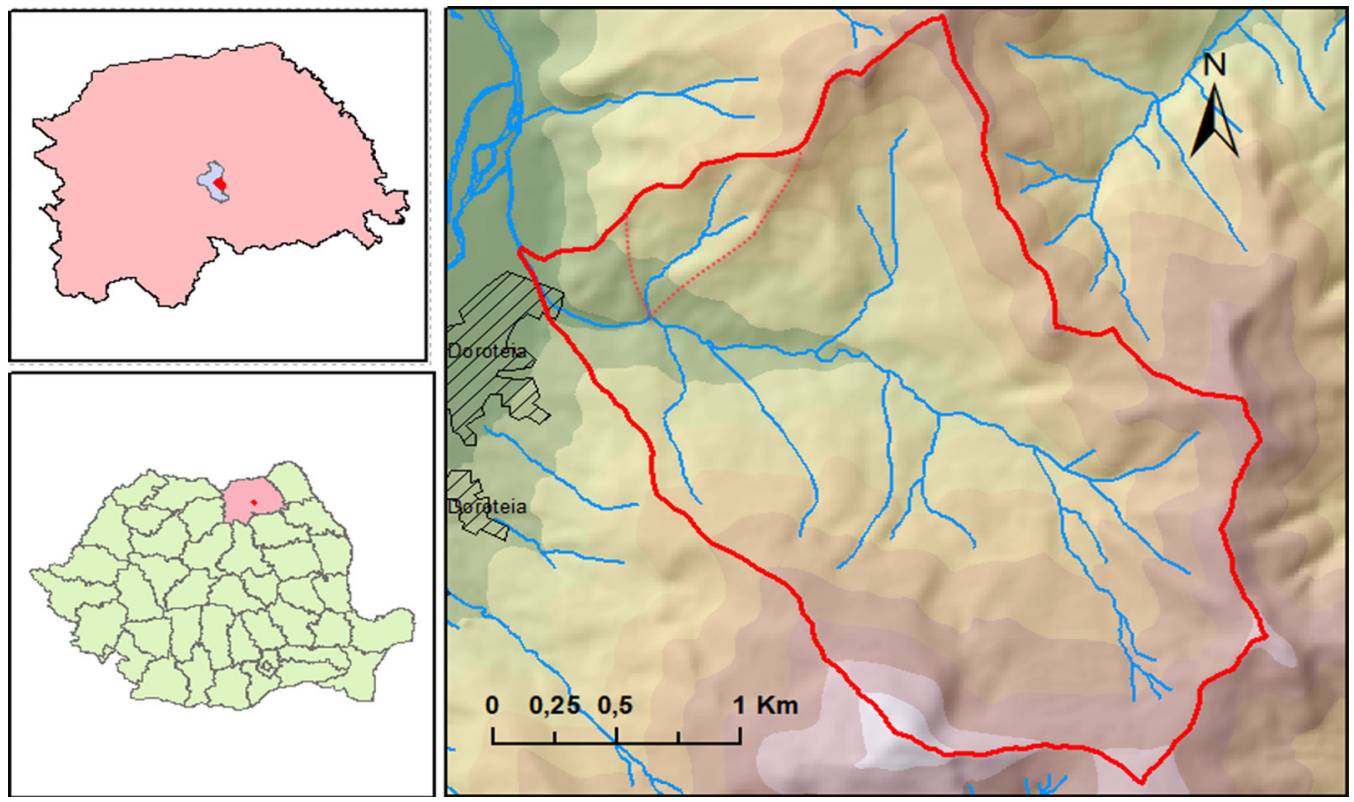

Figura 1 Localizarea Baziului Hidrografic Torențial Doroteia

Location of Doroteia torrential watershed. 
grafic torențial Doroteia (figura 1). Alegerea bazinului Doroteia este justificată de existența unui proiect tehnic complet implementat, care cuprinde o gamă variată de amenajări hidrotehnice care s-au executat într-o singură etapă, cu materiale si tehnologii de execuție omogene, ce pot asigura comparabilitatea costurilor pentru diverse tipuri de lucrări.

Bazinul pârâului Doroteia se află pe raza localității cu același nume din unitatea administrativ teritorială Orașul Frasin, județul Suceava. În acest bazin s-au executat lucrări de corectare a torenților in anii 1979 si 1980 care au drept scop stabilizarea nivelului de baza a rețelei hidrografice și retenția aluviunilor în vederea consolidării malurilor și versanților (Anonymous 1977,1978).

Fondul forestier din cuprinsul bazinului este situat in Ocolul Silvic Frasin, UP II Doroteia.

În conformitate $\mathrm{cu}$ datele din proiect și cu măsurătorile din teren, s-au proiectat și executat:

(i) lucrări hidrotehnice specifice pentru corectarea torenților - pe sectoarele inferioare ale pr Doroteia $(2,88 \mathrm{~km})$ și pr. Staniştea $(0,12$ km) - afluent de dreapta al Pr. Doroteia;

(ii) lucrări de împădurire a terenurilor degradate pe 8,16 ha.

\section{Metoda de lucru}

Cercetările au avut in vedere actualizarea costurilor lucrărilor hidrotehnice existente pentru a putea compara costurile diferitelor tipuri de lucrări. În acest scop s-a folosit programul de devize DevizOnline (https:/www.deviz.ro/ index.php), in care au fost introduse datele cu privire la cantităţile de lucrări, extrase din proiectul de execuție „Corectarea torenților și ameliorarea terenurilor degradate din fondul forestier aferent pârâul Doroteia" (1978) (figura 2).

Instrumentul de bază pentru estimarea costurilor in activitatea de construcții este devizul de lucrări in construcții.

In conformitate $\mathrm{cu}$ obiectivele menționate anterior lucrările de corectarea a torenților executate în bazin au fost grupate în doua tipuri: (i) lucrări transversale si (ii) lucrări longitudinale.

Tipurile de lucrări identificate s-au constituit în obiecte după ce, in cadrul fiecărui tip s-au separat lucrările de terasamente de cele din zidărie.

In funcție de specificul operațiunilor care se derulează pe parcursul executării lucrărilor articolele de antemăsurătoare s-au grupat in doua capitole de lucrări:

(i) Terasamentele - cuprind toate operațiunile care se refera la teren și amenajarea acestuia: săpături, împrăștierea pământului, sprijiniri, compactări, nivelări, finisări, epuismente și transportul pământului;

(ii) Zidăria - include toate operațiunile necesare pentru realizarea corpului lucrărilor: zidăria propriu-zisă, cofraje, schelărie, tencuieli, pregătirea şi transportul pietrei, mortarului, betonului și a celorlalte materiale necesare.

Au rezultat 11 devize (liste de cantități) care au fost introduse în program. In cadrul fiecărui obiect s-au introdus articolele de deviz care descriu operațiunile necesare realizării lucrărilor, pe baza antemăsurătorilor din proiectul de execuţie.

Lucrările de zidărie au fost executate cu mortare si betoane preparate pe șantier în stații necentralizate, folosind norme locale și prețuri reglementate care nu mai pot fi actualizate in prezent. Din aceste motive pentru actualizarea costurilor lucrărilor de zidărie încadrarea pe articole s-a schimbat astfel încât să corespundă procurării mortarelor și betoanelor in stații centralizate, adăugându-se costurile aferente transporturilor de la staţia de betoane cea mai apropiată.

Întrucât la data întocmirii proiectului tehnic normele tehnice utilizate de program nu existau, a fost nevoie ca unele articole din proiect să fie adaptate la normele republicane care au apărut după 1982.

De asemenea aprovizionarea cu piatră nu se mai poate face de la carierele care existau la 


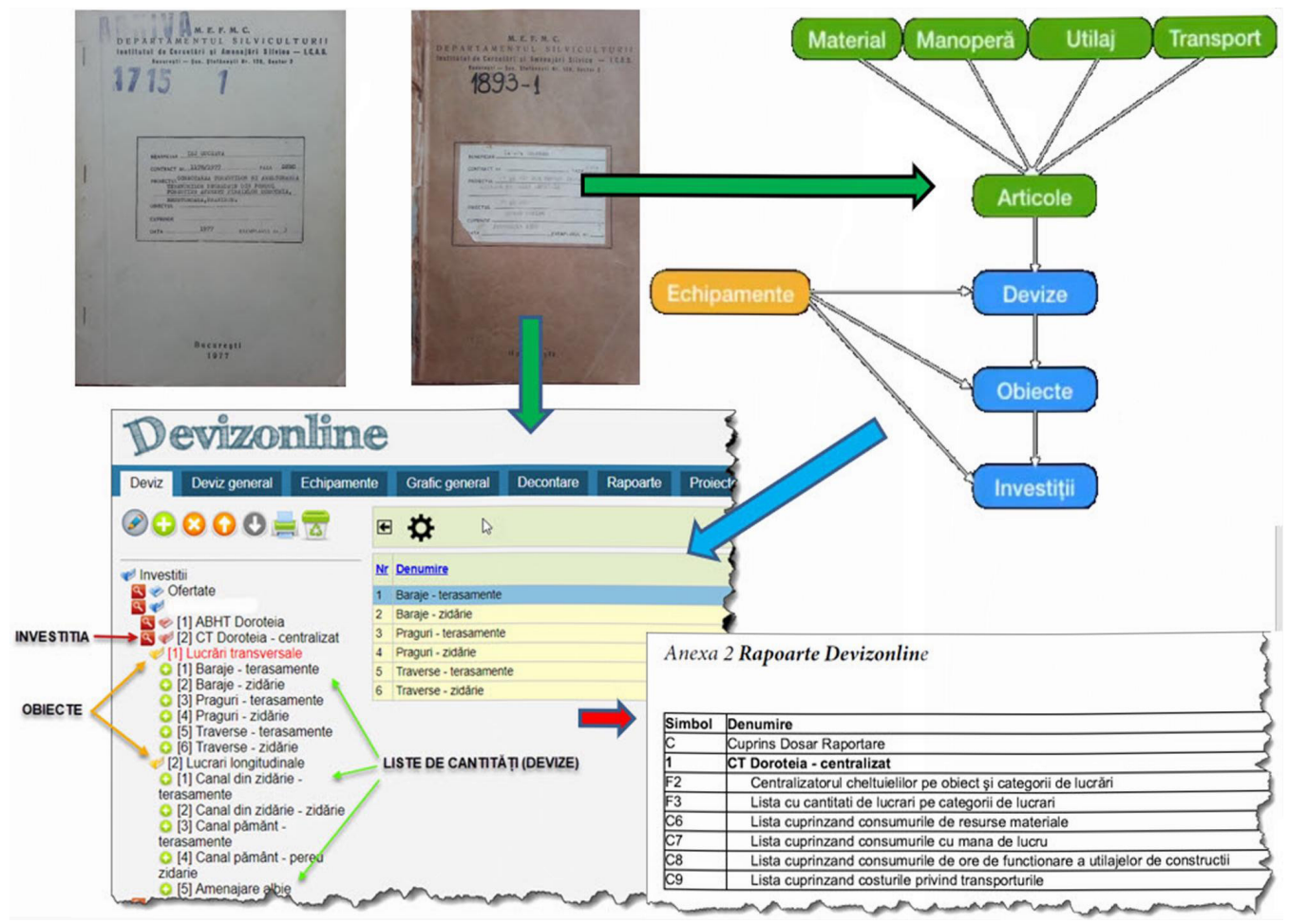

Figura 2 Succesiunea etapelor și modul de prelucrare a informațiilor cu aplicația Deviz Online The sequence of steps and the information processing modality using Deviz Online application

data execuției și de aceea s-a adăugat aprovizionarea cu piatra de la cariera Pojorâta si transportul aferent acestei distanțe de aprovizionare.

La stabilirea costurilor pe fiecare articol de deviz a fost nevoie de preturile unitare, care pe fiecare tip de resursă s-au extras din bazele de preturi de referință ale softului sau din bazele de prețuri ale furnizorilor locali.

Stabilirea preturilor unitare și a costurilor pe fiecare tip de resursă pentru categoriile de lucrări transversale și longitudinale din proiect s-au realizat după extragerea din devize a costurilor totale pe tipuri de resurse si construirea cu acestea a centralizatorului cantitativ valoric. In acest scop s-au folosit rapoartele generate de program (Anexa 2 - material suplimentar).

Din cauza dificultăților de încadrare pe articole, analiza costurilor din prezenta lucrare a exclus lucrările de ameliorare a terenurilor degradate și s-a limitat strict la lucrările de corectarea a torenților grupate pe obiecte: lucrările transversale și lucrările longitudinale.

Prin urmare se poate spune că, costul lucrărilor este actualizat ca și când lucrările s-ar executa cu acelaşi volum și tip de materiale dar cu mijloacele din prezent.

\section{Rezultate și discuții}

\section{Constituirea și structurarea devizelor}

Pornind de la documentațiile tehnice confruntate cu lucrările existente pe teren, s-a realizat evidența lucrărilor hidrotehnice de pe rețeaua hidrografică, cu prezentarea volumului fiecărei lucrări în parte (tabelul 1). 
Tahel1 Lucrări hidrotehnice de corectare a torenților executate in bazinul hidrografic Hydrotechnical works for torrents control executed in the hydrographic basin

\begin{tabular}{|c|c|c|c|c|c|c|c|c|}
\hline \multirow{4}{*}{ Lucrări executate } & & \multicolumn{7}{|c|}{ Categoria de lucrări } \\
\hline & & \multirow{2}{*}{\multicolumn{2}{|c|}{$\begin{array}{l}\text { Lucrări } \\
\text { transversale }\end{array}$}} & \multicolumn{5}{|c|}{ Lucrări longitudinale } \\
\hline & & & & \multicolumn{2}{|c|}{$\begin{array}{l}\text { Canal din } \\
\text { zidărie }\end{array}$} & \multicolumn{2}{|c|}{$\begin{array}{l}\text { Canal din } \\
\text { pământ }\end{array}$} & \multirow{2}{*}{$\begin{array}{l}\begin{array}{l}\text { Amena- } \\
\text { jare } \\
\text { albie }\end{array} \\
\begin{array}{l}\text { Terasa- } \\
\text { mente }\end{array}\end{array}$} \\
\hline & & $\begin{array}{l}\text { Terasa- } \\
\text { mente }\end{array}$ & Zidărie & $\begin{array}{l}\text { Terasa- } \\
\text { mente }\end{array}$ & Zidărie & $\begin{array}{l}\text { Terasa- } \\
\text { mente }\end{array}$ & $\begin{array}{l}\text { Pereu } \\
\text { zidărie }\end{array}$ & \\
\hline Tip lucrare & Simbol lucrare & $(\mathrm{mc})$ & (mc) & (mc) & $(\mathrm{mc})$ & (mc) & $(\mathrm{mc})$ & $(\mathrm{mc})$ \\
\hline \multicolumn{9}{|l|}{ Pârâul Doroteia } \\
\hline Canal din pământ & $1 \mathrm{KTL}=671,5 \mathrm{~m}$ & & & & & 5310,0 & 63,00 & \\
\hline Canal zidărie & $2 \mathrm{ZML}=220,6 \mathrm{~m}$ & & & 2430,0 & 896,0 & & & \\
\hline Amenajare albie & & & & & & & & 1153 \\
\hline Traversă & $3 \mathrm{M} 0 / 2,0$ & 46,0 & 21,0 & & & & & \\
\hline Traversă & $4 \mathrm{M} 0 / 2,0$ & 46,0 & 21,0 & & & & & \\
\hline Traversă & $5 \mathrm{M} 0 / 2,0$ & 46,0 & 21,0 & & & & & \\
\hline Traversă & $6 \mathrm{M} 0 / 2,0$ & 46,0 & 21,0 & & & & & \\
\hline Traversă & $7 \mathrm{M} 0 / 2,0$ & 41,0 & 23,0 & & & & & \\
\hline Traversă & $8 \mathrm{M} 0 / 2,0$ & 56,0 & 30,0 & & & & & \\
\hline Prag & $9 \mathrm{M} 1.0$ & 43,0 & 28,0 & & & & & \\
\hline Baraj & $10 \mathrm{M} 2,5$ & 387,0 & 190,0 & & & & & \\
\hline Prag & $11 \mathrm{M} 0,5$ & 50,0 & 42,0 & & & & & \\
\hline Baraj & $12 \mathrm{M} 2,0$ & 307,0 & 169,0 & & & & & \\
\hline Baraj & $13 \mathrm{M} 1,5$ & 277,0 & 156,0 & & & & & \\
\hline Baraj & $14 \mathrm{M} 2,5$ & 332,0 & 301,0 & & & & & \\
\hline Prag & $15 \mathrm{M} 0,5$ & 62,0 & 41,0 & & & & & \\
\hline Prag & $16 \mathrm{M} 0,5$ & 62,0 & 41,0 & & & & & \\
\hline Prag & $17 \mathrm{M} 1,0$ & 55,0 & 41,0 & & & & & \\
\hline $\begin{array}{l}\text { Traverse canal } \\
\text { pământ ( } 2 \text { buc) }\end{array}$ & & 1378,0 & 54,0 & & & & & \\
\hline Prag & $18 \mathrm{M} 0,5$ & 58,0 & 38,0 & & & & & \\
\hline Prag & 19M1,0 & 55,0 & 38,0 & & & & & \\
\hline Prag & $20 \mathrm{M} 1,0$ & 55,0 & 38,0 & & & & & \\
\hline Total 1 & & 3402,0 & 1314,0 & 2430,0 & 896,0 & 5310,0 & 63,0 & 1153,0 \\
\hline \multicolumn{9}{|l|}{ Pârâul Staniștea } \\
\hline Baraj & $1 \mathrm{M} 3,0$ & 169,0 & 115,0 & & & & & \\
\hline Baraj & $2 \mathrm{M} 3,0$ & 169,0 & 118,0 & & & & & \\
\hline Baraj & $3 \mathrm{M} 3,0$ & 169,0 & 118,0 & & & & & \\
\hline Total 2 & & 507,0 & 351,0 & 0,00 & 0,00 & 0,00 & 0,00 & 0,00 \\
\hline
\end{tabular}


Analiza datelor privind lucrările hidrotehnice existente, indică faptul că indiferent de tip, pentru aceeași lucrare volumul terasamentelor este mai mare decât volumul de zidărie (Tabelul 1, Figura 3).

De asemenea, rapoartele dintre volumele terasamente/zidărie indică faptul ca valorile mediane cele mai mici sunt la baraje şi că aceste rapoarte cresc de la baraje la praguri și la traverse (Figura 3).

Pe de altă parte, volumul aferent unui metru cub de traversă este mai mare decât volumul echivalent de la praguri, care la rândul său este mai mare decât volumul de aterisamente ce revine unui metru cub de baraj (Figura 4).
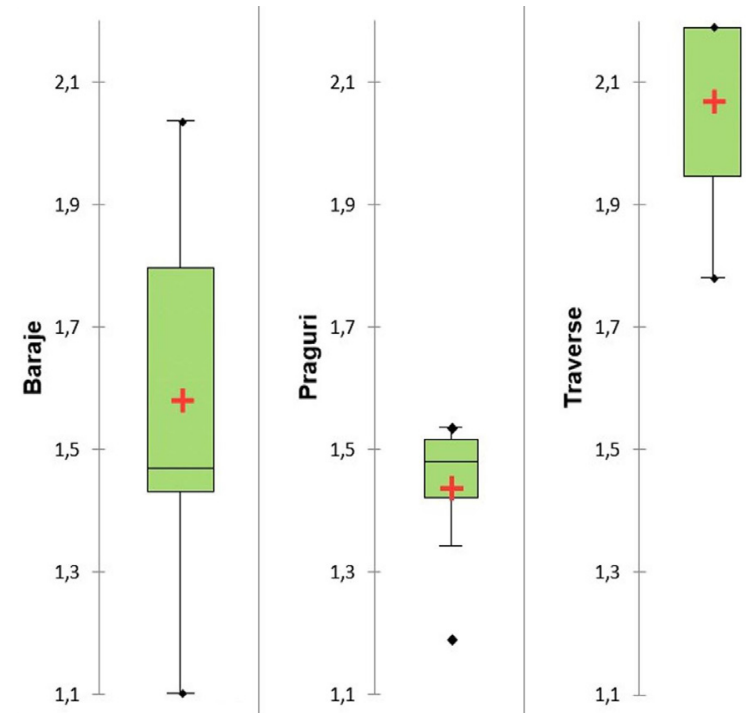

Figura 3 Diagramele Boxplot ale rapoartelor dintre volumul terasamentelor/zidăriei

Boxplots for masonry/embankment volumes report

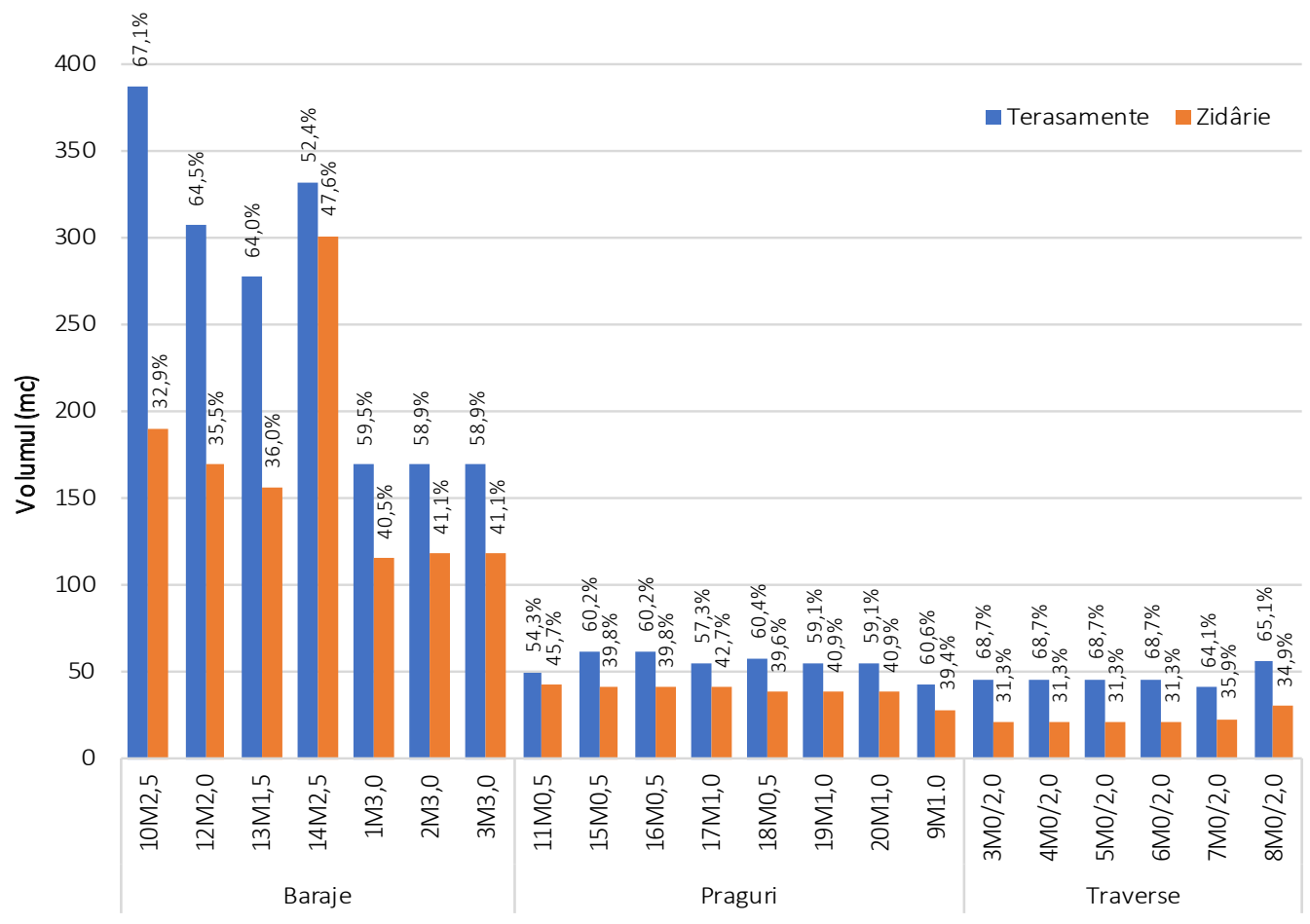

Tip de lucrare

Figura 4 Distribuția volumului terasamentelor și zidăriei în cazul lucrărilor transversale Distribution of the masonry and the embankments of the transversal works 
Tahel 2 Extras din centralizatorul antemăsurătorilor la lucrările transversale (Material suplimentar, Anexa 1) Reprint of the pre-measurement centralisation of the transversal works (Supplementary material, Annex1)

\begin{tabular}{|c|c|c|}
\hline $\begin{array}{l}\text { Nr. } \\
\text { crt. }\end{array}$ & $\begin{array}{c}\text { Simbolul } \\
\text { lucării }\end{array}$ & Descrierea lucrării \\
\hline \multicolumn{3}{|c|}{ 9A. TERASAMENTE } \\
\hline 1 & TSA07D1 & Sapatura manuala de $\mathrm{p}$ \\
\hline 2 & TSA07H1 & Sapatura manuala de $p$ \\
\hline 3 & TSA07D2 & Sapatura manuala de $\mathrm{p}$ \\
\hline 4 & TSA07H2 & Sapatura manuala de $\mathrm{p}$ \\
\hline 5 & TSB21B1 & Sapatura in stanca in $\mathrm{s}$ \\
\hline 6 & TSB21E1 & Sapatura in stanca in $\mathrm{s}$ \\
\hline 7 & TSD01D1 & Imprastierea cu lopata \\
\hline 8 & TSD04A1 & Compactarea cu maiul \\
\hline 9 & TSE01C1 & Nivelarea manuala a te \\
\hline 10 & TSF05A1 & Sprijiniri de maluri,cu du \\
\hline 11 & TSF06A1 & Sprijiniri de maluricu du \\
\hline 12 & TSF07A1 & Sprijiniri de maluri,cu du \\
\hline 13 & TSA24C1 & Epuizarea mecanica a \\
\hline \multirow[t]{2}{*}{14} & TRB01C13 & Transportul materialelo \\
\hline & TOTALA & \\
\hline \multicolumn{3}{|c|}{ 9B. ZIDARIE } \\
\hline 1 & CD01A3 & Zidărie din piatră brutà \\
\hline 2 & CD01B3 & Zidărie din piatră brută \\
\hline 3 & $\mathrm{CA01C4}$ & Turnarea betonului simp \\
\hline 4 & CA01A1 & Turnarea betonului simp \\
\hline 5 & CB47A1 & Schela metalica tubular \\
\hline 6 & CB11E1 & Cofraje pentru beton in \\
\hline 7 & CB11F1 & Cofraje pentru beton in \\
\hline 8 & IFC09B1 & Jgheaburi din lemn, cu sca \\
\hline 9 & ACE17A1 & Placa indicatoare montata \\
\hline 10 & CF06C1 & Tencuieli exterioare obi \\
\hline 11 & TRA06A20 & Transportul rutier al betor \\
\hline 12 & TRB04A2 & Transportul materialelor \\
\hline 13 & TRA01A50 & Transport piatră de caries \\
\hline 14 & TRB01C12 & Transportul materialelor \\
\hline 15 & TRB05B22 & Transportul materialelor \\
\hline & TOTALB & \\
\hline
\end{tabular}

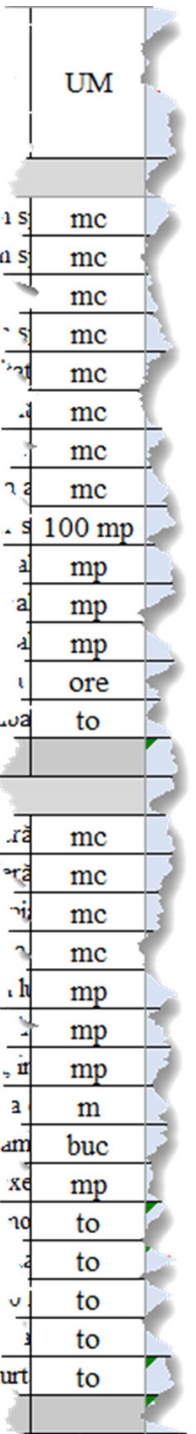

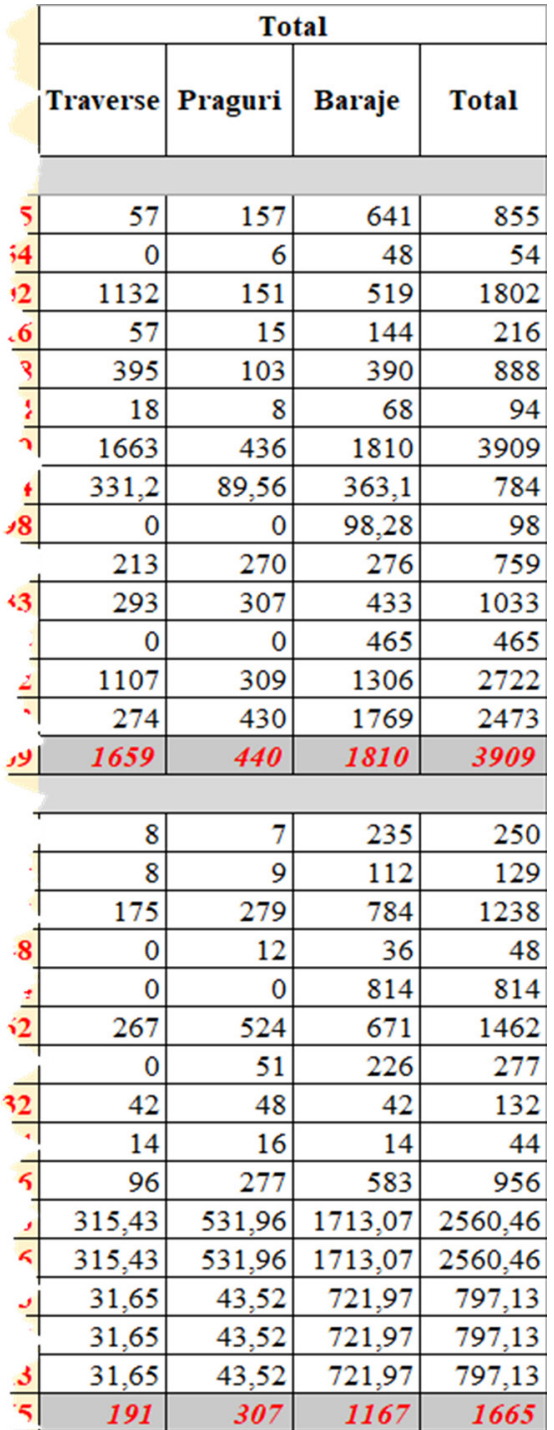

Operațiunile necesare pentru executarea lucrărilor transversale s-au constituit în 29 de articole cu totaluri separate care indică volumul de săpătură la lucrările de terasamente și volumul de zidărie care este același cu volumul lucrării (Material suplimentar, Anexa 1).

Pentru executarea canalului din pământ sunt necesare 13 operațiuni concretizate în tot atâtea articole de deviz, iar la canalul din zidărie antemăsurătoarea si devizul conțin 29 de articole. 114

\section{Prețurile unitare pe articol de deviz}

La stabilirea costurilor pe fiecare articol de deviz a fost nevoie de preturile unitare, care pe fiecare tip de resursă s-au extras din bazele de preturi de referință ale softului sau din bazele de prețuri ale furnizorilor locali. Preturile unitare pentru fiecare tip de resursă sunt prezentate in listele cuprinzând consumurile de resurse, care sunt prezentate parțial in figura 5 . 
Tahel 3 Extras antemăsurătoare canal din pământ $1 \mathrm{KTL}=671,5 \mathrm{~m}$

Reprint of the pre-measurement for ditch from the ground $1 \mathrm{KTL}=671.5 \mathrm{~m}$

\begin{tabular}{|c|c|c|c|c|}
\hline Pozitie & Simbol & Denumire & $\mathbf{U M}$ & Cantitate \\
\hline \multicolumn{5}{|c|}{ I. Terrasamente canal pământ } \\
\hline 1 & TSC19C1 & Sapatura mecanica cu buldozer pe tractor & $100 \mathrm{mc}$ & 21,2 \\
\hline 2 & TSC22E1 & e de ore-utilaj din & $100 \mathrm{mc}$ & 57,6 \\
\hline 3 & $\mathrm{TSC} 0$ & tor pe pneuri de & $100 \mathrm{mc}$ & 21,2 \\
\hline 4 & TSA01D2 & spatii intinse & $\mathrm{mc}$ & 1070 \\
\hline 5 & TRB01C12 & a pe pneuri i & tona & 1526 \\
\hline 6 & TRA03A01 & Transport rutier materiale,semifabricate $\mathrm{cu}$ ? & tona & 5680 \\
\hline 7 & TSE04C1 & Nivelarea terenului natural si platformelor de & $100 \mathrm{mp}$ & 275 \\
\hline 8 & TSE03D1 & a taluzurilor,in t. teren $\mathrm{fc}$ & $100 \mathrm{mp}$ & 62 \\
\hline 9 & TSC02D1 & Sapatura mecanica cu excavator pe pneuri ds & $100 \mathrm{mc}$ & 31,5 \\
\hline 10 & TRI1AA01C & Incarcarea materialelor, grupa a-grele si mart, & tona & 5630 \\
\hline \multicolumn{5}{|c|}{ II. Pereu zidarie canal pamant } \\
\hline 1 & IFB11F1 & Strat din piatr & $\mathrm{me}$ & 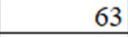 \\
\hline 2 & IFB12A1 & i uscat din piatra bruta sau $\mathrm{k}^{\circ}$ & $\mathrm{mp}$ & 126 \\
\hline 3 & TRA01A50 & Transport piatră de cariera la $50 \mathrm{kr}$ & tona & \\
\hline
\end{tabular}

Tahel 4 Extras antemăsurătoare canal din zidărie $2 Z M L=220,6 \mathrm{~m}$

Reprint of the pre-measurement for ditch from the embankments $2 Z M L=220.6 \mathrm{~m}$

\begin{tabular}{|c|c|c|}
\hline Pozitie & Simbol & Denumire \\
\hline \multicolumn{3}{|c|}{ I Terasamente la canal zidărie } \\
\hline 1 & TSA07D1 & Sapatura manuala de pamant,in spatii limitate,ar \\
\hline 2 & TSA07D2 & Sapatura manuala de pamant,in spatii limitate,ava \\
\hline 3 & TSA07H2 & Sapatura manuala de pamant, in spatii limitate,ava \\
\hline 4 & TSB21B1 & Sapatura in stanca in spatii limitate, de peste $1 \mathrm{~m}$ \\
\hline 5 & TSB21E1 & Sapatura in stanca in spatii limitate, de peste $1 \mathrm{~m}$ \\
\hline 6 & TSA05D1 & a manuala de pamant in $\mathrm{s}$ \\
\hline 7 & TSA & ra manuala de pamant in spatii limitate,ave \\
\hline 8 & TSA05G2 & e pamant in spatii limitate,avar \\
\hline 9 & TRB & inc \\
\hline 10 & TRF & inc as \\
\hline 11 & TRA & fabricate cu autotr \\
\hline 12 & TRA & utotre \\
\hline 13 & TRI1 & unte, $\mathrm{p}$ \\
\hline 14 & TSF & rizon \\
\hline 15 & TSA & teren. \\
\hline 16 & TSL & a cu lopata a pamant. afinat,strat unifu. \\
\hline 17 & TSD04C1 & ea cu maiul de mana a umpluturilor ev \\
\hline \multicolumn{3}{|c|}{ II. Zidărie la canal zidărie } \\
\hline 1 & CD01A3 & Zidărie din pi \\
\hline 2 & CD01B3 & Zidărie din piatră brută de ca \\
\hline 3 & $\mathrm{CA}$ & atii,zio \\
\hline 4 & $\mathrm{CAO}$ & Turnarea betonului simplu marca...1) în fundatii c \\
\hline 5 & CB11E1 & , inclusin sprijinis \\
\hline 6 & ACE17A1 & Placa indicatoare montata la camine rezerv. sau \\
\hline 7 & CF06A1 & Tencuieli exterioare obișnuite executate manual, $d$ \\
\hline 8 & TRA06A20 & Transportul rutier al betonului-mortarului cu autobet \\
\hline 9 & TRB04A2 & Transportul materialelor cu lopata(max.3m oriz sau \\
\hline 10 & TRA01A50 & Transport piatră de cariera la $50 \mathrm{~km}$ \\
\hline 11 & TRB01C12 & Transportul materialelor cu roaba pe pneuri inc arun \\
\hline 12 & TRB05B22 & Transportul materialelor prin purtat direct,material \\
\hline
\end{tabular}

\begin{tabular}{|c|c|c|}
\hline & $\mathbf{U M}$ & Cantitate \\
\hline$+\sqrt{1}$ & $\mathrm{mc}$ & 13 \\
\hline & $\mathrm{mc}$ & 42 \\
\hline th & $\mathrm{mc}$ & 13 \\
\hline & $\mathrm{mc}$ & 14 \\
\hline 3 & $\mathrm{mc}$ & 3 \\
\hline at & $\mathrm{mc}$ & 1010 \\
\hline ati & $\mathrm{mc}$ & 960 \\
\hline ati & $\mathrm{mc}$ & 375 \\
\hline$t$ & tona & 423 \\
\hline$t$ & tona & 2470 \\
\hline T & tona & 540 \\
\hline 4 & tona & 907 \\
\hline t & tona & 1450 \\
\hline 1 & $\mathrm{mp}$ & 141 \\
\hline 7 & ora & 1 \\
\hline-1 & $\mathrm{mc}$ & 2430 \\
\hline 1 & $\mathrm{mc}$ & 2430 \\
\hline 1 & & \\
\hline vof & $\mathrm{mc}$ & 333 \\
\hline vas & $\mathrm{mc}$ & 356 \\
\hline $\mathrm{u}$ & $\mathrm{mc}$ & 48 \\
\hline & $\mathrm{mc}$ & 159 \\
\hline re & $\mathrm{mp}$ & 1080 \\
\hline$\Rightarrow$ & buc & 2 \\
\hline- & $\mathrm{mp}$ & 7 \\
\hline co & to & 990,29 \\
\hline 1] & to & 990,29 \\
\hline & to & 1520,09 \\
\hline-10 & to & 1520,09 \\
\hline 2 & to & 1520,09 \\
\hline
\end{tabular}


Structura generală a costurilor pe tipuri de lucrări și capitole de cheltuieli

Valoarea totală a lucrărilor de bază pentru corectarea torenților, in lei, fără TVA, la data de 10 iunie 2018 este de 2.818.903,09 lei. Actualizarea s-a făcut la această dată pentru ca preturile să nu fie afectate de Hotărârea de Guvern nr. 937/2018 şi de Ordonanța de urgență nr. 114/2018. Această valoare a fost

\section{Formularul C6 - Lista cuprinzand consumurile de resurse materiale}

\begin{tabular}{|c|c|c|c|c|c|c|c|c|c|}
\hline $\mathrm{Nr}$ & Simbol & $\begin{array}{c}\text { Denumirea resursei } \\
\text { materiale }\end{array}$ & Furnizorul & Cantitatea & UM & $\begin{array}{l}\text { Protul unitar } \\
\text { (Lei) }\end{array}$ & $\begin{array}{l}\text { Protul total } \\
\text { (Lei) }\end{array}$ & Groutate & $\begin{array}{c}\text { Cost } \\
\text { transport } \\
\text { (Lei) }\end{array}$ \\
\hline 1 & 7300112 & $\begin{array}{l}\text { Acid azotic tehnic stas } \\
447-64 \text { tip } 96 \text { conc.min } 96,5 \%\end{array}$ & Depozit & 60,6250 & $\mathrm{~kg}$ & 1,5000 & 90,938 & $\begin{array}{l}0,0752 \\
1\end{array}$ & 0,00 \\
\hline 2 & 6202806 & $\begin{array}{l}\text { Apa industriala pentru } \\
\text { lucr.drumuri-terasamente in } \\
\text { cisterne }\end{array}$ & Depozit & 321,3860 & $m c$ & 0,1607 & 51,662 & 321,3860 & \\
\hline 3 & 6202818 & Apa industriala pentru mortare & Depozit & 268.3140 & $m c$ & 0,1607 & 43,131 & & \\
\hline
\end{tabular}

Formularul C7 - Lista cuprinzand consumurile cu mana de lucru

\begin{tabular}{|c|c|c|c|c|c|}
\hline $\mathrm{Nr}$ & Simbol & Denumirea meseriei & Cantitatea & Pretul unitar (Lei) & Pretul total (Lei) \\
\hline 1 & 10221 & Betonist categoria a II-a & 72,4500 & 11,5000 & 833,175 \\
\hline 2 & 10211 & Betonist categoria I & 948,1200 & 11,5000 & 10903,380 \\
\hline 3 & 10721 & Dulgher constructii categoria a II-a & 2331,5553 & 11,5000 & 26812,886 \\
\hline 4 & 10731 & Dulgher constructii categoria a III-a & 881,1100 & 11,5000 & 10132,765 \\
\hline 5 & 10741 & Dulgher constructii categoria a IV- a & 458,1800 & 11,5000 & 5269,070 \\
\hline 6 & 10711 & Dulgher constructii categoria I & 1725,2200 & 11,5000 & 19840,030 \\
\hline 7 & 11021 & Fascinar categoria a II-a & 29,9244 & 11,5000 & 344,130 \\
\hline 8 & 11011 & Fascinar categoria I & 89,7744 & 11,5000 & 1032,405 \\
\hline 9 & 11321 & Finaor terasamente categoria & 3081,5271 & 11,5000 & $35,437,562$ \\
\hline
\end{tabular}

Formularul C8 - Lista cuprinzand consumurile de ore de functionare a utilajelor de constructii

\begin{tabular}{|c|c|c|c|c|c|}
\hline $\mathrm{Nr}$ & Simbol & Denumirea utilajului de constructii & Cantitatea & Pretul unitar (Lei) & Pretul total (Lei) \\
\hline 1 & 7301 & Bob elevator mobil cu electromotor de $4.5 \mathrm{kw}$ & 0,0560 & 30,0000 & 1,688 \\
\hline 2 & 3554 & Buldozer pe senile $81-180 \mathrm{cp}$ & 118,0510 & 140,0000 & 16527,149 \\
\hline 3 & 2801 & Ciocan pneum(exclusiv consum aer) 8-15 kg & 4317,3001 & 50,0000 & 215865,00 \\
\hline 4 & 3521 & $\begin{array}{l}\text { Excavator pe pneuri motor termic (buldoexcavator) } \\
0.21-0.39 \mathrm{mc}\end{array}$ & 243,3230 & 130,0000 & 31631,99 \\
\hline 5 & 2509 & Motocompresor mobil joasa presiune $4.0-5.9 \mathrm{mc} / \mathrm{min}$ & 2158,6500 & 45,0000 & 97139,258 \\
\hline 6 & 4704 & $\begin{array}{l}\text { Motopompa apa monoetaj de jpres.mont.pe tractor pn. } \\
65 \mathrm{cP}\end{array}$ & 4012,0000 & 35,0000 & 140420,009 \\
\hline
\end{tabular}

\section{Formularul C9 - Lista cuprinzand costurile privind transporturile}

\begin{tabular}{|c|c|c|c|c|c|}
\hline $\mathrm{Nr}$ & Simbol & Tipul de transport & Tone transportate & Pretul unitar (Lei) & Pretul total (Lei) \\
\hline 1 & 30049 & $\begin{array}{l}\text { Transport dutier materiale.semifabricate cu autotractor pe } \\
\text { pneuri cu remorca pe distanta } 0.5 \mathrm{~km}\end{array}$ & 1447,0000 & 1,0000 & 1447,000 \\
\hline 2 & 30050 & $\begin{array}{l}\text { Transport rutier materiale.semifabricate cu autotractor pe } \\
\text { pneuri cu remorca pe distanta } 1 \mathrm{~km}\end{array}$ & 5680,0000 & 2,0260 & 11507,680 \\
\hline 3 & 30101 & $\begin{array}{l}\text { Transport rutier materiale.semifabricate cu autotractor pe } \\
\text { pneuri cu remorca pe distanta } 50 \mathrm{~km}\end{array}$ & 124,6100 & 42,0000 & 5233,620 \\
\hline 4 & 39295 & Tranenertul nutier al betonylui_mortarului cu autobetoniera & 3550,7500 & 18,0090 & 000 \\
\hline
\end{tabular}

Figura 5 Extras din listele care cuprind consumurile de resurse

Reprint of the list containing resources input 
calculată pe baza devizelor pe fiecare tip de lucrare pornind de la cantitățile pe fiecare articole de deviz cu ajutorul preturilor unitare actualizate pentru fiecare resursă conform formularelor C6-C8 din Metodologia elaborată de Guvernul României, privind elaborarea devizului general şi a devizului pe obiect din 29.11.2016, publicată în Monitorul Oficial, Partea I nr. 1061 din 29 decembrie 2016.

Cheltuielile direct productive s-au obținut prin însumarea costurilor $\mathrm{cu}$ materialele + manopera + utilaje + transport.

Valoarea totală a cheltuielilor directe a rezultat prin însumarea costurilor directe menționate anterior cu cota de 2,25 \% din manoperă
- care reprezintă contribuția asiguratorie pentru muncă.

Cheltuielile indirecte s-au obținut prin aplicarea unui procent de $10 \%$ la totalul cheltuielilor directe.

Pentru a obține valoarea totală s-a adăugat o cotă de profit de $5 \%$ care se aplică după ce se cumulează totalul cheltuielilor directe cu cheltuielile indirecte (Tabelul 5).

Se constată că din valoarea totală a lucrărilor $86,6 \%$ reprezintă cheltuielile directe, 8,7 $\%$ sunt cheltuieli directe, iar profitul reprezintă $4,7 \%$ din totalul cheltuielilor pentru realizarea lucrărilor de bază din bazin.

Tahel 5 Structura costurilor pe categorii de lucrări şi tipuri de cheltuieli Cost structure by categories of works and types of expenses

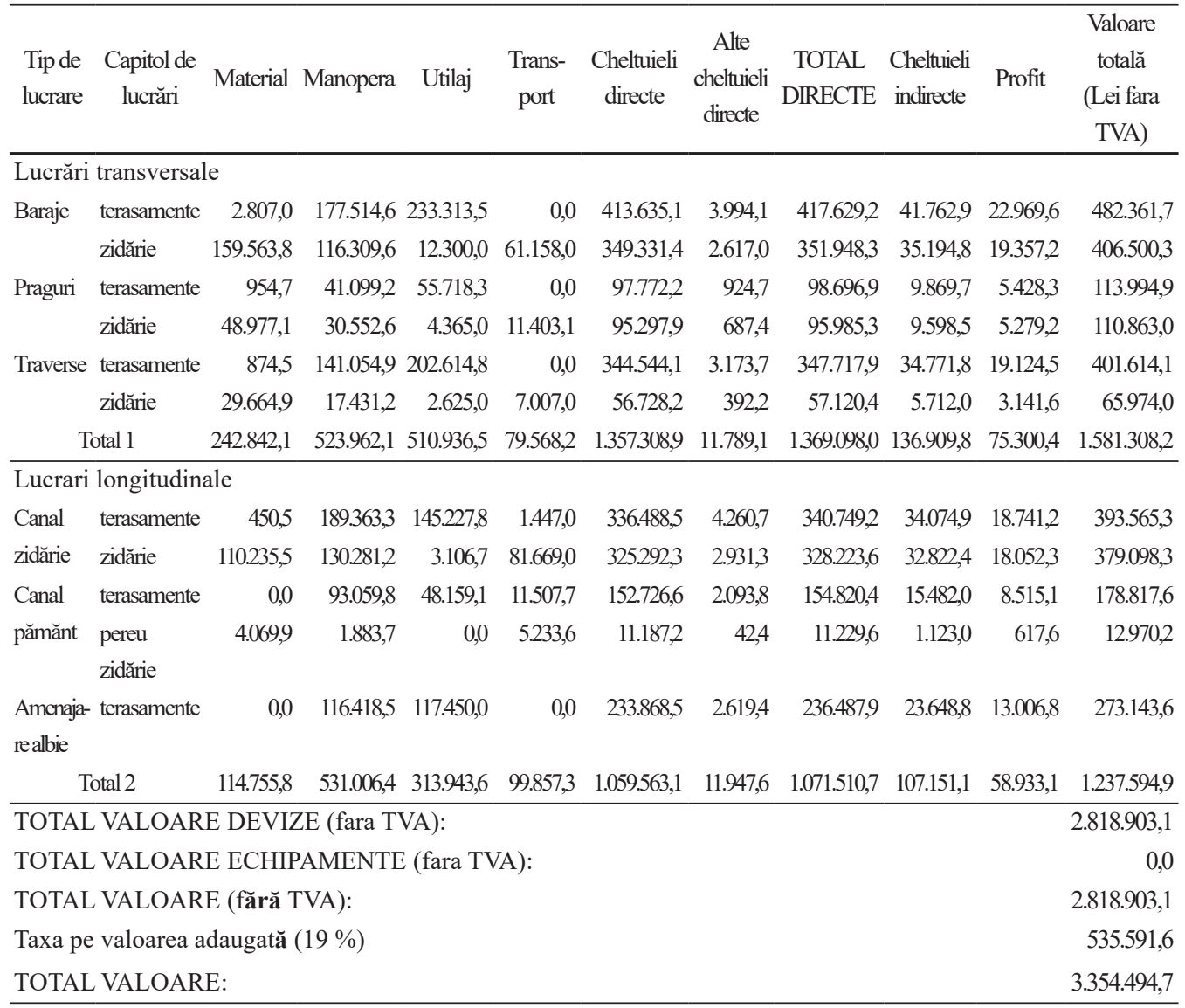




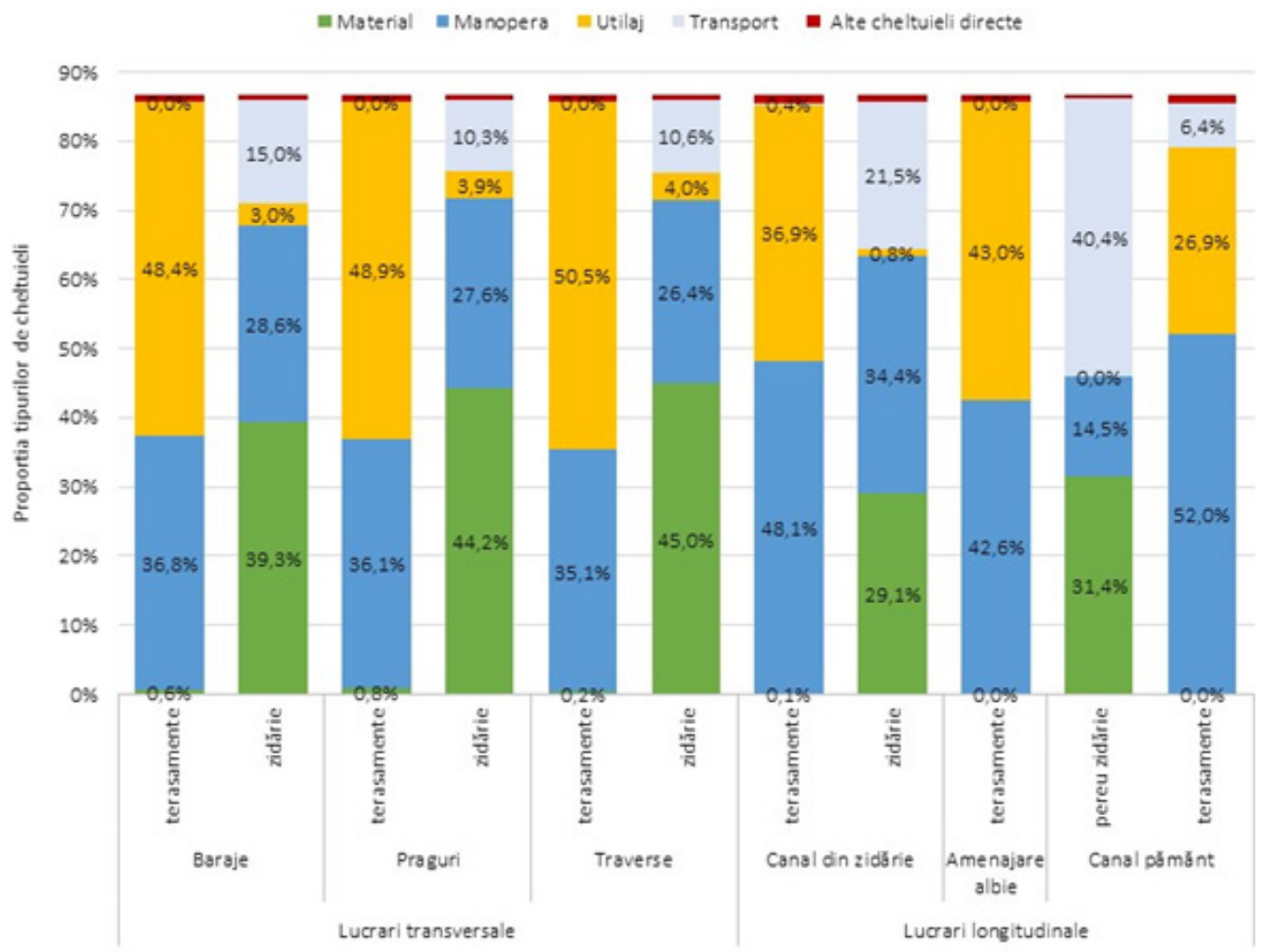

Figura 6 Structura cheltuielilor directe pe tipuri și capitole de lucrări

Structure of direct expenses by types and chapters of works

Analizând distribuția costurilor pe categorii, tipuri și capitole de lucrări, raportate la costurile totale ale tipurilor de lucrări, constatăm următoarele:

a) Lucrările de terasamente:

(i) nu conțin costuri generare de consumul unor resurse materiale iar cheltuielile cu transportul sunt nesemnificative;

(ii) în medie, proporția costurilor cu manopera este mai mare la lucrările longitudinale iar cheltuielile cu utilajele sunt mai mari la lucrările transversale;

(iii) la lucrările transversale proporția costurilor cu manopera înregistrează o uşoară scădere de la baraje - praguri - traverse dar se mențin peste o cotă de $35 \%$ în totalul cheltuielilor directe;

(iv) proporția cheltuielilor cu utilajele crește odată cu scăderea inălţimii utile a lucrărilor 118 transversale.

b) Lucrările de zidărie:

(i) Proporția osturilor cu utilajele este mai mică de 4\% la lucrările transversale dar de aproape 10 ori mai mare la cele longitudinale;

(ii) Costurile materialelor înregistrează o proporție de peste 39\% la lucrările transversale și se mențin la 30\% din valoarea cheltuitelor totale, in cazul lucrărilor longitudinale;

(iii) La lucrările transversale proporția cheltuielilor cu materialele creste in ordinea descreșterii inălțimii utile, baraje - praguri traverse, iar transporturile înregistrează o tendință descrescătoare la succesiunea de lucrări menționată;

(iv) Proporția cheltuielilor $\mathrm{cu}$ manopera crește pe măsura creșterii volumului zidăriei și a complexității lucrărilor - de la traverse spre baraje. 
Tabel 6 Centralizator cantitativ-valoric

\begin{tabular}{|c|c|c|c|c|c|c|}
\hline $\begin{array}{l}\text { Nr. } \\
\text { crt. }\end{array}$ & Tip de lucrare & Capitol de lucrări & UM & Cantități & $\begin{array}{l}\text { Preț unitar } \\
\text { lei/UM }\end{array}$ & $\begin{array}{l}\text { Valoare totală } \\
\text { (Lei fără TVA) }\end{array}$ \\
\hline 1 & \multicolumn{6}{|c|}{ Lucrări transversale } \\
\hline 1.1 & \multirow{2}{*}{ Baraje } & terasamente & $\mathrm{mc}$ & 1810 & 266,50 & $482.361,73$ \\
\hline 1.2 & & zidărie & $\mathrm{mc}$ & 1167 & 348,33 & $406.500,34$ \\
\hline 1.3 & \multirow{2}{*}{ Praguri } & terasamente & $\mathrm{mc}$ & 440 & 259,08 & $113.994,95$ \\
\hline 1.4 & & zidărie & $\mathrm{mc}$ & 307 & 361,12 & $110.863,02$ \\
\hline 1.5 & \multirow{3}{*}{ Traverse } & terasamente & $\mathrm{mc}$ & 1659 & 242,08 & $401.614,14$ \\
\hline 1.6 & & zidărie & $\mathrm{mc}$ & 191 & 345,41 & $65.974,02$ \\
\hline Total 1 & & & & & & $1.581 .308,19$ \\
\hline 2 & \multicolumn{6}{|c|}{ Lucrări longitudinale } \\
\hline & \multirow{2}{*}{ Canal din zidărie } & terasamente & $\mathrm{mc}$ & 2430 & 161,96 & $393.565,30$ \\
\hline 2.2 & & zidărie & $\mathrm{mc}$ & 896 & 423,10 & $379.098,28$ \\
\hline 2.3 & \multirow{2}{*}{ Canal pământ } & terasamente & $\mathrm{mc}$ & 5310 & 33,68 & $178.817,57$ \\
\hline 2.4 & & pereu zidărie & $\mathrm{mc}$ & 63 & 205,88 & $12.970,18$ \\
\hline 2.5 & \multirow[t]{2}{*}{ Amenajare albie } & terasamente & $\mathrm{mc}$ & 1153 & 236,90 & $273.143,57$ \\
\hline Total 2 & & & & & & $1.237 .594,90$ \\
\hline \multicolumn{6}{|c|}{ TOTAL VALOARE DEVIZE (fără TVA): } & $2.818 .903,09$ \\
\hline \multicolumn{6}{|c|}{ TOTAL VALOARE ECHIPAMENTE (fără TVA): } & 0,00 \\
\hline \multicolumn{6}{|c|}{ TOTAL VALOARE (fără TVA): } & $2.818 .903,09$ \\
\hline \multicolumn{6}{|c|}{ Taxa pe valoarea adăugată (19 \%): } & 535591,5867 \\
\hline \multicolumn{6}{|c|}{ TOTAL VALOARE: } & $3.354 .494,67$ \\
\hline
\end{tabular}

(v) Datele confirmă faptul că costurile generate de transport sunt direct proportionale cu volumul de piatră utilizat la zidărie și de distanţa de transport a acesteia; in cazul e față comparabilitatea costurilor de transport. pentru diverse tipuri de lucrări, poate fi realizată fiindca distanța de transport este aceeași.

\section{Preturi unitare pe categorii de lucrări}

Raportând costurile totale din devize la cantitățile de lucrări pe capitole și tipuri de lucrări s-au obținut prețurile unitare pe categorii de lucrări (Tabelul 6).

In cazul lucrărilor de terasamente se constată că cele mai mari valori ale prețurilor unitare se înregistrează la baraje; urmează o descreștere ușoară la praguri și traverse și se constată o scădere semnificativă la terasamentele canalului din zidărie (Figura 7).

La lucrările din zidărie prețurile unitare pe metru cub de zidărie nu înregistrează o tendință clară in cazul lucrărilor transversale, dar se remarcă prin valoare mai mare in cazul lucrărilor longitudinale (Figura 8).

In practica amenajării torenților se menționează un trend descrescător al prețurilor unitare pe mc de zidărie de la baraje spre traverse, dar numai in cazul văilor cu deschideri de albii constante. Pe pr. Doroteia traversele sunt amplasate pe sectorul inferior unde albia este îngustă, iar pragurile și barajele pe un sector 


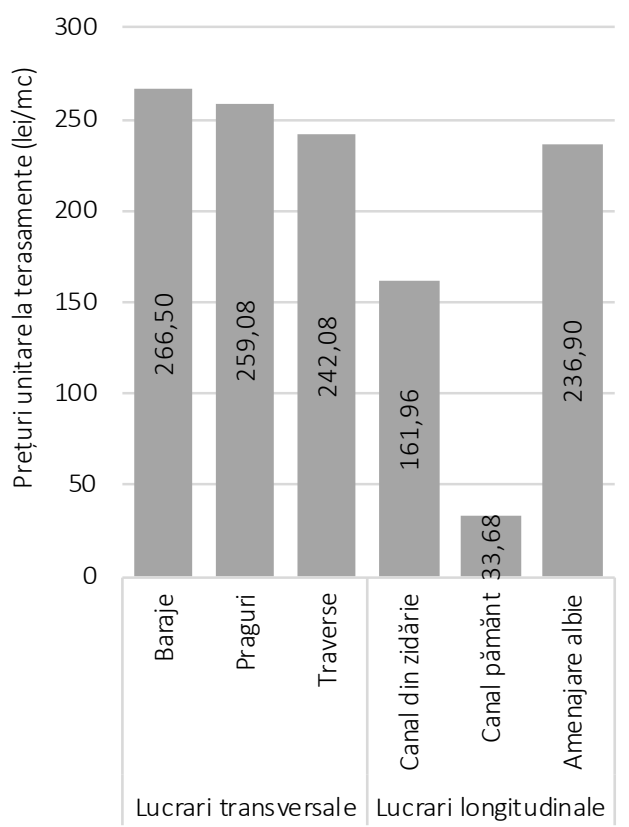

Figura 7 Preturile unitare (lei/mc) la lucrările de terasamente

Unit prices (lei $\left./ \mathrm{m}^{3}\right)$ for earthworks
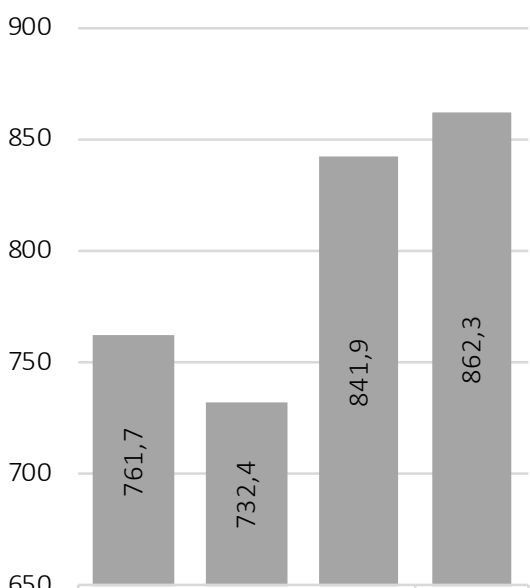

Figura 9 Preturile unitare (lei/mc) la volum lucrare Unit prices (lei $\left./ \mathrm{m}^{3}\right)$ for work volume

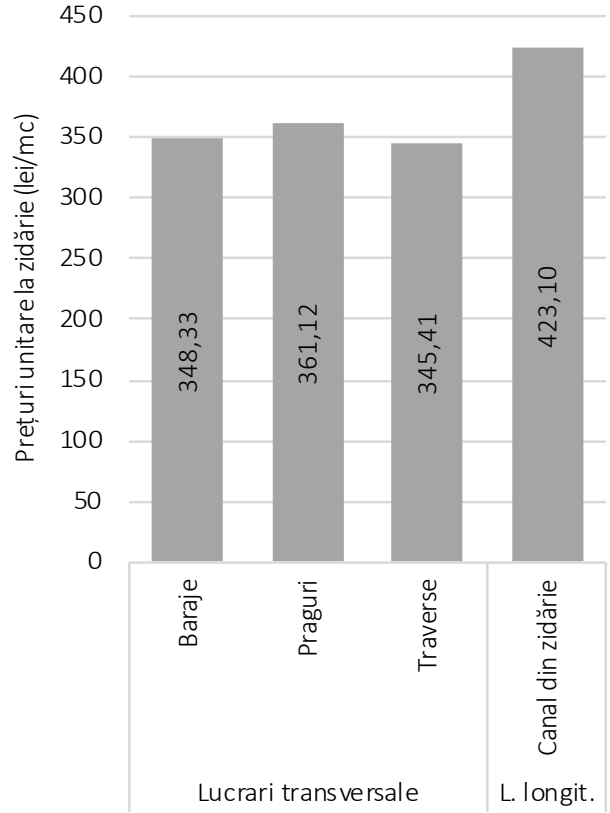

Figura 8 Preturile unitare (lei/mc) la lucrările de zidărie Unit prices (lei $\left./ \mathrm{m}^{3}\right)$ for masonry works

cu albie largă - unde lățimea albiei devine determinantă în volumul lucrării.

Prin raportarea prețurilor unitare cumulate pe terasamente și zidărie la volumul lucrării, (care este egal cu volumul de zidărie) se obțin prețurile unitare pe metru cub de lucrare, care sunt foarte utile la estimarea costurilor in studiile de fezabilitate. Aceste prețuri unitate sunt mai mari la traverse decât la baraje și praguri pentru că în cazul traverselor proporția terasamentelor care revine fiecărui metru cub de lucrare este mai mare decât în cazul barajelor şi al pragurilor (Figura 9).

Acest fapt prezintă importanță practică la estimarea cu ajutorul prețurilor unitare a costului unor lucrări transversale. Rezultă de aici că la lucrările transversale, cu cât raportul volumelor terasamente/zidărie este mai mare cu atât costurile unitare vor crește. $\mathrm{Cu}$ alte cuvinte preturile unitare la traverse sunt mai mari decât ale pragurilor si barajelor. Această constatare poate fi aplicată la văile care nu-și modifică semnificativ deschiderea pe sectorul cu lucrări. 


\section{Cu privire la actualizarea valorilor investiției}

Potrivit proiectului tehnic, valoarea lucrărilor de bază pentru corectare a torenților la nivelul anului 1977 sunt:

$\begin{array}{lr}\text { Anul I } & 2.387 .900,0 \text { lei } \\ \text { Anul II } & 187.200,0 \text { lei } \\ \text { TOTAL } & 2.575 .100,0 \text { lei }\end{array}$

Valoarea actualizată a acestor lucrări prin recalcularea devizelor in cadrul prezentei lucrări, in lei la data 10 iunie 2018 este:

Total valoare devize (fara TVA): $\quad 2.818 .903,1$ lei Total valoare (fara TVA): $\quad 2.818 .903,1$ lei Taxa pe valoarea adăugată (19 \%): $\quad 535.591,6$ lei TOTAL VALOARE: 3.354.494,7 lei
Raportul dintre valorile totale calculate in devize și costul total al acelorași lucrări in anul 1977 este 1,09 fără TVA și 1,30 cu TVA.

Actualizarea cu ajutorul indicelui anual al preturilor de consum (IPC) presupune înmulțirea valorii proiectului din 1977 cu produsul IPC anuali pana la data actualizării a cărui valoare a fost determinată in tabelul 7 , potrivit datelor Institutului National de Statistică (http://statistici.insse.ro/shop/?page=ipc1\&lang=ro) este IPC1977-2018=6009,928. Acest mod de actualizare conduce la valori aberante.

Prin urmare, rezultă că actualizarea preturilor la astfel de lucrări nu de poate face decât recalculând în prețuri actuale devizele acestor lucrări.

Tahel 1 Indicele mediu anual al preturilor de consum (IPC) furnizat de INS

Annual average consumer price index (IPC) provided by INS

\begin{tabular}{|c|c|c|}
\hline Anul & & $\mathrm{C}$ \\
\hline 1977 & 100,00 & 1 \\
\hline 1978 & 101,60 & 1,016 \\
\hline 1979 & 102,00 & 1,02 \\
\hline 1980 & 102,10 & 1,021 \\
\hline 1981 & 103,10 & 1,031 \\
\hline 1982 & 117,80 & 1,178 \\
\hline 1983 & 104,10 & 1,041 \\
\hline 1984 & 101,10 & 1,011 \\
\hline 1985 & 100,80 & 1,008 \\
\hline 1986 & 101,00 & 1,01 \\
\hline 1987 & 100,90 & 1,009 \\
\hline 1988 & 102,20 & 1,022 \\
\hline 1989 & 101,10 & 1,011 \\
\hline 1990 & 105,10 & 1,051 \\
\hline
\end{tabular}

\begin{tabular}{lll}
\hline Anul & \multicolumn{2}{c}{ IPC } \\
1991 & 270,20 & 2,702 \\
1992 & 310,40 & 3,104 \\
1993 & 356,10 & 3,561 \\
1994 & 236,70 & 2,367 \\
1995 & 132,30 & 1,323 \\
1996 & 138,80 & 1,388 \\
1997 & 254,80 & 2,548 \\
1998 & 159,10 & 1,591 \\
1999 & 145,80 & 1,458 \\
2000 & 145,70 & 1,457 \\
2001 & 134,50 & 1,345 \\
2002 & 122,50 & 1,225 \\
2003 & 115,30 & 1,153 \\
2004 & 111,90 & 1,119 \\
\hline
\end{tabular}

\begin{tabular}{lll}
\hline Anul & \multicolumn{2}{c}{ IPC } \\
2005 & 109,00 & 1,0900 \\
2006 & 106,56 & 1,0656 \\
2007 & 104,84 & 1,0484 \\
2008 & 107,85 & 1,0785 \\
2009 & 105,59 & 1,0559 \\
2010 & 106,09 & 1,0609 \\
2011 & 105,79 & 1,0579 \\
2012 & 103,33 & 1,0333 \\
2013 & 103,98 & 1,0398 \\
2014 & 101,07 & 1,0107 \\
2015 & 99,41 & 0,9941 \\
2016 & 98,45 & 0,9845 \\
2017 & 101,34 & 1,0134 \\
IPC $_{1977-2018}=$ & 6009,928 \\
\hline
\end{tabular}

\section{Concluzii}

Studiul arată că actualizarea costurilor la lucrările de corectare a torenților care au fost executate înainte de 1989 nu se poate face decât recalculând în prețuri actuale devizele acestor lucrări, ca si cum aceleași lucrări s-ar executa

din nou cu același volum și tip de materiale dar cu mijloacele din prezent.

Întrucât de la data întocmirii proiectelor tehnice normele de deviz au suferit mai multe modificări și completări care s-au concretizat in edițiile din 1981, 1991, 1999 şi 2006 este nevoie ca unele operațiuni și lucrări să fie re- 
încadrate pe articole pentru a putea actualiza costurile; reîncadrarea devine obligatorie la proiectele elaborate înainte de anul 1981 când s-au publicat primele norme de deviz republicane.

Varianta de actualizare a investițiilor vechi cu ajutorul indicelui de anual al preturilor de consum este nefezabilă deoarece conduce la valori actualizate aberante, care sunt determinate de modificările care s-au produs de-a lungul timpului pe piața financiara și de.

Comparând tipurile de lucrări transversale s-a constatat că indiferent de tipul lucrării volumul terasamentelor este mai mare decât volumul de zidărie aferent aceleiași categorii.

Prețurile unitate (obținute prin raportarea prețurilor unitare cumulate pe terasamente și zidărie la volumul lucrării = volumul de zidărie) diferă semnificativ de la o categorie de lucrări transversale la alta, aceste diferențele rămânând semnificative și atunci când se compară preturile unitare la baraje, praguri și traverse.

\section{Bihliografie}

Anonymous 1977. Documentaţie de fundamentare a notei de comandă (DFNC): Corectarea torenților și ameliorarea terenurilor degradate din fondul forestier aferent pâraielor Doroteia, Brusturoasa, Braniște, beneficiar ISJ Suceava, ICAS București

Anonymous 1978. Proiect de execuție: Corectarea torentilor și ameliorarea terenurilor degradate din fondul forestier aferent pârâul Doroteia, beneficiar ISJ Suceava, ICAS București

Anonymous 1995. Normativ pentru proiectarea lucrărilor de amenajarea a bazinelor hidrografice torențiale. ICAS București, 255+224 p.

Anonymous, 2017. Guvernul României - Hotărâre nr. 907 din 29 noiembrie 2016 privind etapele de elaborare şi conţinutul-cadru al documentațiilor tehnico-economice aferente obiectivelor/proiectelor de investiţii finanţate din fonduri publice. În vigoare de la 27 februarie 2017. Monitorul Oficial, Partea I nr. 1061 din 29 decembrie 2016, București.

Bouzit M., 1999. Éléments méthodologiques pour l'évaluation économique des dispositifs de protection contre les risques torrentiels. Rapport pour le compte du ministère de l'Aménagement du territoire et de l'Environnement, convention Cemagref Montpellier $n^{\circ}$ 17/98. pp. 35 p. + annexes.
Brochot S., Duclos P. și Bouzit M., 2003. L'évaluation économique des risques torrentiels: intérêts et limites pour les choix collectifs de prévention. Ingénieries numéro spécial" risques, 53-68.

Ciornei I. și Drăgoi M., 2014. Dynamics of hydrological parameters in a small torrential basin covered with fullstocked forests. Journal of Horticulture, Forestry and Biotechnology, Vol 18(2) (Editura Agroprint Timișoara), 223.

Ciornei I. și Grudnicki F., 2010. Amenajarea bazinelor hidrografice torențiale prin lucrări specifice. In Cursuri și lucrări practice, Universitatea "Ștefan cel Mare", Suceava, pp. 167.

Clinciu I., 2001. Corectarea torenţilor - curs universitar. Ediţia a II-a. Reprografia Universităţii Transilvania din Braşov: Braşov, 248 p.

Clinciu I., 2011. Cercetări privind lucrările de amenajare a rețelei hidrografice torenţiale din bazinul superior al Târlungului (amonte de acumularea Săcele). Editura Universităţii Transilvania din Braşov, 400 p.

Drăgoi M., 2000. Economie forestieră. Editura Economică: București, $288 \mathrm{p}$.

Drăgoi M., 2008. Economie și management forestier. Editura Universităţii din Suceava: Suceava, 334 p.

Duclos P., Bouzit M. și Brochot S., Year. Published Application d'une méthode d'analyse économique à la définition d'une stratégie de protection in Éléments d'aide à la programmation des investissements contre les risques naturels et à l'élaboration de plans de prévention des risques (PPR), Tacnet J, pp. 5-99.

Gaşpar R., 2005. Comportarea lucrărilor hidrotehnice de amenajare a torentilor, o problema de actualitate a cercetării științifice. Revista Pădurilor (5), 36-43.

Griffin R.C., 1998. The fundamental principles of cost-benefit analysis. Water Resources Research, 34 (8), 2063-2071.

Milescu I., 2002. Economie forestieră. Grupul editorial Crai noi-Muşatinii-Bucovina viitoare: Suceava, 292 p.

Munteanu S.A., Traci C., Clinciu I., Lazăr N., Untaru E. și Gologan N., 1993. Amenajarea bazinelor hidrografice torenţiale prin lucrări silvice şi hidrotehnice. Volumul II Amenajarea rețelei hidrografice torentiale și fectele lucrarilor de amenajare a bazinelor hidrografice torentiale. Editura Academiei Române: București, 311 p.

Treich N., 2005. L'analyse coût-bénéfice de la prévention des risques. Version préliminaire. LERNA-INRA, Université de Toulouse, 52.

Verrier C., 1980. Coûts et avantages des travaux RTM - Cas des voies de communication, mémoire de $3 \mathrm{e}$ cycle de l'IGA VERRIER de Grenoble, pour le compte du Cemagref, $143 \mathrm{p}$.

\section{Material suplimentar}

Varianta online a articolului conține material suplimentar.

Anexa1. Centralizatorul lucrărilor transversale

Anexa2. Lista consumurilor de resurse/Rapoarte DevizOnline 